\title{
On the evolution of the thermocline and subthermocline eastward currents in the Equatorial Atlantic
}

\author{
B. Bourlès, 'M. D'Orgeville, ${ }^{2}$ G. Eldin, ${ }^{3}$ Y. Gouriou, ${ }^{4}$ R. Chuchla, ${ }^{1}$ Y. DuPenhoat, ${ }^{3}$ \\ and S. Arnault ${ }^{5}$ \\ Received 11 March 2002; accepted 6 June 2002; published 23 August 2002.
}

[1] Eastward currents in the thermocline and subthermocline layers of the tropical Atlantic Ocean are described using observations obtained during two boreal summer cruises covering the whole equatorial basin. The analysis focuses on the eastward evolution of zonal currents in the thermocline and sub-thermocline. The Equatorial Undercurrent is not found close to the African coast in boreal summer 2000, maybe because of interannual variability. As observed in the Pacific, the South and North Equatorial Undercurrents are shown to shift poleward from west to east, and the two cruises indicate that the North Equatorial Undercurrent does not enter the Gulf of Guinea. The South and North Intermediate Countercurrents are variable with longitude and, contrarily to the observations in the eastern equatorial Pacific, are not found in the east of the Guinea basin. INDEXTERMS: 4231 Oceanography: General: Equatorial oceanography; 4512 Oceanography: Physical: Currents; 4572 Oceanography: Physical: Upper ocean processes; 9325 Information Related to Geographic Region: Atlantic Ocean

\section{Introduction}

[2] The equatorial Atlantic Ocean is a key region with regard to the large-scale oceanic circulation. There, cold North Atlantic Water flows southward in the deep layers after it is formed by convection in the northern polar region. This flow is compensated by a flow of warm surface and intermediate waters from the southern to the northern hemisphere. This large-scale meridional circulation contrasts with the quasi-zonal currents observed within the thermocline and sub-thermocline layers of the tropical Atlantic basin. While far from being understood, the link between this large-scale meridional circulation and the zonal equatorial circulation has been often investigated in the western tropical Atlantic from numerous cruises, mooring deployments, float trajectories and model results [Schott et al., 1995, 1998; Boebel et al., 1999; Bourlès et al., 1999]. On the other hand measurements in the central and eastern part of the basin are sparse (see Stramma and Schott [1999], hereafter $S t S c 99$, for a review and schematics). This lack of observations restrains our comprehension of the equatorial circulation. Here, we present observations of zonal currents in the thermocline and subthermocline layers all along the

\footnotetext{
'Centre IRD de Brest, Plouzané, France.

${ }^{2} \mathrm{LPO} / \mathrm{Ifremer}$, Plouzané, France.

${ }^{3}$ IRD, LEGOS, Toulouse, France

${ }^{4}$ Centre IRD de Nouméa, France.

${ }^{5}$ IRD, LODYC, Paris, France.
}

Atlantic equatorial basin during two cruises carried out in boreal summer 1999 and 2000. These measurements allow to follow the zonal extension and to examine the possible steadiness of this zonal currents system; they are compared with the schematics of $S t S c 99$, representative of the mean circulation conditions.

\section{Data}

[3] Data used in this study were acquired during the two EQUALANT cruises, as part of the ECLAT (Etudes Climatiques dans l'Atlantique Tropical) program, a French contribution to CLIVAR (Climate Variability and predictability). These cruises included five meridional sections (Figure 1) carried out on board R/V Thalassa from July 13 to August 21, 1999 (at $35^{\circ} \mathrm{W}, 23^{\circ} \mathrm{W}$ and $10^{\circ} \mathrm{W}$ ), and from July 25 to August 20,2000 (at $10^{\circ} \mathrm{W}, 0^{\circ} \mathrm{E}$ and $6^{\circ} \mathrm{E}$ ). The $10^{\circ} \mathrm{W}$ section was thus repeated at 11 months interval. The 1999 and 2000 cruises will be referred as EQ1 and EQ2 respectively. Velocity profiles, from $30 \mathrm{~m}$ to about $700 \mathrm{~m}$ depth, were measured with a VM-ADCP (RDI $75 \mathrm{kHz}$ ), with a $16 \mathrm{~m}$ vertical bins resolution. During each cruise, absolute referencing was provided by GPS navigation. The original 5 minutes mean values were averaged into ' $1 / 4$ degree' profiles. Estimated through their standard deviation, the accuracy of these mean profiles is generally better than $2.5 \mathrm{~cm} \mathrm{~s}^{-1}$ [Eldin, 2001]. Hydrological measurements were made with a Seabird-SBE911+ $\mathrm{CTDO}_{2}$ probe, with water samples for conductivity and oxygen sensors calibration and tracers measurement. Pressure and temperature sensors were calibrated before and after each cruise.

\section{Results}

[4] Depth-latitude sections of zonal velocity are presented on Plate 1. Our main interest is in the eastward evolution of the following eastward flowing currents: the Equatorial Undercurrent (EUC), found between $2^{\circ} \mathrm{N}$ and $2^{\circ} \mathrm{S}$ and with a velocity core located around $100 \mathrm{~m}$ depth, the North and South Equatorial Undercurrents (NEUC and SEUC), located around $4^{\circ} \mathrm{N}$ and $4^{\circ} \mathrm{S}$ in the $100-300 \mathrm{~m}$ depth range, and the North and South Intermediate Currents (NICC and SICC), found around $1^{\circ} 30 \mathrm{~N}$ and $1^{\circ} 30 \mathrm{~S}$ below $300 \mathrm{~m}$ depth.

\subsection{The Equatorial Undercurrent (EUC)}

[5] At $35^{\circ} \mathrm{W}$ the EUC lies between $2^{\circ} \mathrm{S}$ and $2^{\circ} \mathrm{N}$, with a maximum velocity core $\left(80 \mathrm{~cm} \mathrm{~s}^{-1}\right)$ south of the equator around $100 \mathrm{~m}$ depth. At $23^{\circ} \mathrm{W}$, the EUC shrinks between $1^{\circ} \mathrm{S}$ and $1^{\circ} \mathrm{N}$, but its velocity core $\left(65 \mathrm{~cm} \mathrm{~s}^{-1}\right)$ is thicker than at $35^{\circ} \mathrm{W}$, in relationship with the vertical stretching of 


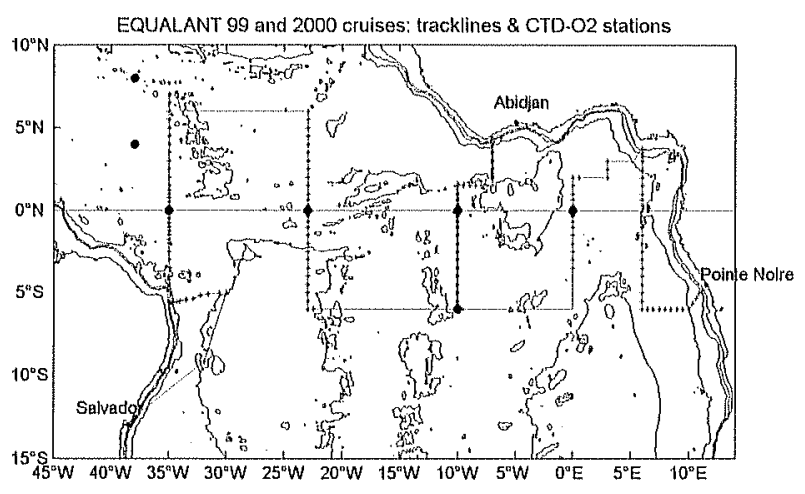

Figure 1. Tracks of the Equalant cruises, with station positions (dots): EQ1 (July 13 to August 21, 1999; blue dots) and EQ2 (July 25 to August 20, 2000; red dots).

isopycnals. At $35^{\circ} \mathrm{W}$ and $23^{\circ} \mathrm{W}$ the EUC is deeper north of the equator than south of it. We note the presence of a strong westward flowing SEC north of the equator above the EUC. At $10^{\circ} \mathrm{W}$ during EQ1, the maximum velocity core $(>70 \mathrm{~cm}$ $\mathrm{s}^{-1}$ ) is measured south of the equator at $50 \mathrm{~m}$ depth. At $23^{\circ} \mathrm{W}$ and $10^{\circ} \mathrm{W}$, eastward flow extends below the EUC down to $400 \mathrm{~m}$. At $10^{\circ} \mathrm{W}$ during EQ1, this current is quite strong with velocity greater than $50 \mathrm{~cm} \mathrm{~s}^{-1}$ down to $200 \mathrm{~m}$. At $10^{\circ} \mathrm{W}$ during $\mathrm{EQ} 2$, the EUC maximum velocity core is measured north of the equator at about the same depth and with the same intensity than during EQ1, and the only difference between the two cruises is found in the latitudinal position of the EUC core. During EQ2, eastward flow penetrates as deep as during EQ1 below the EUC, but with weaker velocity. Several indices show that the current below $200 \mathrm{~m}$ is not a deep extension of the EUC. Firstly, there are differences in water mass properties, the EUC being characterized by salinity and oxygen maxima above $200 \mathrm{~m}$; secondly, there is a weak westward flow at $35^{\circ} \mathrm{W}-250 \mathrm{~m}$ and a relative minimum of eastward flow at $10^{\circ} \mathrm{W}-250 \mathrm{~m}$ during EQ2 separating the EUC from the deeper flow; thirdly there is a distinct maximum of eastward velocity at $10^{\circ} \mathrm{W}-300 \mathrm{~m}$ during EQ2. The EUC transport (above the isopycnal $\sigma_{0}=$ 26.5 ) is $13.9 \mathrm{~Sv}$ at $35^{\circ} \mathrm{W}, 11.1 \mathrm{~Sv}$ at $23^{\circ} \mathrm{W}, 15.3 \mathrm{~Sv}$ at $10^{\circ} \mathrm{W}$ during EQ1 and $11.8 \mathrm{~Sv}$ at $10^{\circ} \mathrm{W}$ during EQ2, in agreement with previous estimates [Gouriou and Reverdin, 1992; Schott et al., 1998; Bourlès et al., 1999]. Farther east, at $0^{\circ} \mathrm{E}$, the EUC core velocity is strongly reduced $\left(40 \mathrm{~cm} \mathrm{~s}^{-1}\right.$ around $50 \mathrm{~m}$ depth); the EUC thickness does not exceed 30 meters, and it lies entirely beneath the isopycnal $\sigma_{0}=26.25$, that is below the thermocline. Its transport reaches only 5.9 Sv. Such a downstream weakening of the EUC, mainly due to the erosion of its upper part, is linked to thermocline shoaling, to equatorial upwelling and to enhanced vertical mixing, that are generally maximum at this time of year [Wacongne, 1989; Peterson and Stramma, 1991; Gouriou. and Reverdin, 1992]. At $6^{\circ} \mathrm{E}$, the EUC is absent and replaced by westward flow. To our knowledge, this is the first time that the EUC is not observed at this longitude in the Atlantic Ocean. Sparse direct current measurements obtained in the easternmost part of the basin always indicated the presence of the EUC, whatever the time of year, even erođed and weak [Hénin et al., 1986; Hisard and
Hénin, 1987; Wacongne and Piton, 1992; Mercier et al., 2002]. Earlier salinity and oxygen distributions analysis (waters with high salinity and oxygen contents have a western origin and are advected eastward partly within the EUC) showed the EUC splitting into two poleward coastal undercurrents into the Bight of Biafra to the north and within the Gabon-Congo Undercurrent (GCUC) along the African coast to the south [Wacongne and Piton, 1992]. Relative salinity and oxygen maxima at $6^{\circ} \mathrm{E}$ around $3^{\circ} \mathrm{S}$ and $2^{\circ}-3^{\circ} \mathrm{N}$ on and below the $\sigma_{0}=26.25$ isopycnal (not shown) that could not be attributed to the SEUC and NEUC indicate that the lower part of the EUC earlier reached these far eastern longitudes.

\subsection{The South and North Equatorial Undercurrents (NEUC and SEUC)}

[6] At $35^{\circ} \mathrm{W}$, the eastward SEUC is found between 200 $\mathrm{m}$ and $500 \mathrm{~m}$ depth around $3^{\circ} 30 \mathrm{~S}$. As it is close to its formation region off the coast of Brazil, its transport above the $\sigma_{0}=26.75$ isopycnal is only $2 \mathrm{~Sv}$, similar to the
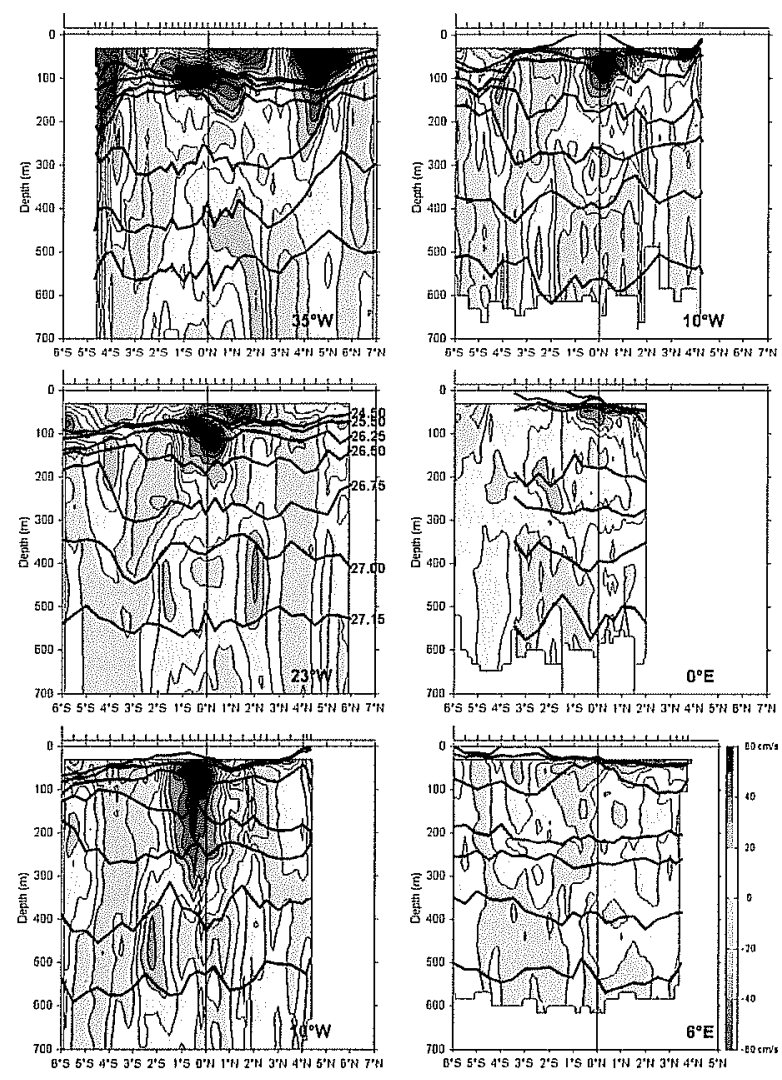

Plate 1. Latitude-depth sections of the zonal component of current velocity, in $\mathrm{cm} \mathrm{s}^{-1}$, along $35^{\circ} \mathrm{W}, 23^{\circ} \mathrm{W}$ and $10^{\circ} \mathrm{W}$ during Equalant 99 (left, from top to bottom), and along $10^{\circ} \mathrm{W}, 0^{\circ} \mathrm{E}$ and $6^{\circ} \mathrm{E}$ during Equalant 2000 (right, from top to bottom). Eastward (westward) currents are positive (negative). Contour interval is $5 \mathrm{~cm} \mathrm{~s}^{-1}$. Station positions are reported on the top of every section (note the absence of stations south of $3^{\circ} \mathrm{S}$ along $0^{\circ} \mathrm{E}$ ). Also drawn are the isopycnals $\sigma_{0}=24.5,25.5,26.25,26.5,26.75,27.0$ and 27.15 . 
estimates obtained by Schott et al. [1995] and Bourles et al. [1999]. As already observed in September 1995 by Bourles et al. [1999], the velocity core of the NEUC is not distinguishable as it lies just beneath the North Equatorial Countercurrent (NECC). However the southward deepening of the isopycnals between $5^{\circ} \mathrm{N}$ and $3^{\circ} \mathrm{N}$ reveals its presence around $150 \mathrm{~m}$ depth at $4^{\circ} \mathrm{N}$. At $23^{\circ} \mathrm{W}$, the SEUC is centered at $4^{\circ} \mathrm{S}-150 \mathrm{~m}$ and the NEUC, weaker than the SEUC, around $5^{\circ} 30 \mathrm{~N}$. At $10^{\circ} \mathrm{W}$, the position of the SEUC is at $5^{\circ} 30 \mathrm{~S}$ and $4^{\circ} \mathrm{S}$ for the two cruises respectively. That may be the signature of interannual variability or the sign of a meandering behaviour, as already suggested by Arhan el al. [1998]. At $10^{\circ} \mathrm{W}$, the eastward flow at $3^{\circ}-4^{\circ} \mathrm{N}$ at the depth of the NEUC is very weak and is not linked to an equatorward sinking of the isopycnals. Furthermore, its water mass characteristics (low salt and oxygen concentrations, not shown) do not correspond to those of the NEUC. Thus, as suggested by its northward veering between $35^{\circ} \mathrm{W}$ and $23^{\circ} \mathrm{W}$, the NEUC does not enter the Gulf of Guinea, in agreement with earlier observations [Arhan et al., 1998; StSc99]. The SEUC is not observed at $0^{\circ} \mathrm{E}$ which could be a consequence of the poleward divergence of this current, as already observed by Tsuchiya [1986] and Mercier et al. [2002]. This is also indicated by VM-ADCP measurements, along with temperature and salinity profiles obtained with $\mathrm{XCTD}$ and XBT probes, carried out in 2000 during the transit at $6^{\circ} \mathrm{S}$ between $10^{\circ} \mathrm{W}$ and $0^{\circ} \mathrm{E}$, that show the SEUC crossing this section toward the south around $3^{\circ} \mathrm{W}$ (not shown). The poleward divergence of these currents during their course toward the east was also found in observations made in the Pacific Ocean [Rowe et al., 1999].

\subsection{The South and North Intermediate Countercurrents (SICC and NICC)}

[7] The SICC and NICC have been defined in the western basin by Schott et al. [1995, 1998] and Boebel et al. [1999] as two off-equatorial eastward intermediate currents located around $2^{\circ} \mathrm{S}$ and $2^{\circ} \mathrm{N}$ respectively and surrounding the westward flowing Equatorial Intermediate Current (EIC), between 400 and $1000 \mathrm{~m}$ depth. Eastward currents, extending from $300 \mathrm{~m}$ to $700 \mathrm{~m}$ are visible at $23^{\circ} \mathrm{W}$ and $10^{\circ} \mathrm{W}$ around $2^{\circ} \mathrm{S}$ and $2^{\circ} \mathrm{N}$. They exhibit velocity cores between the 27.0 and 27.15 isopycnals at $23^{\circ} \mathrm{W}$ and $10^{\circ} \mathrm{W}$ during EQ1 that are representative of the SICC and NICC. At $35^{\circ} \mathrm{W}$, these currents are not so well defined within this isopycnal range, and they are suggested below $500 \mathrm{~m}$ depth only. At $10^{\circ} \mathrm{W}$ the NICC is weaker than the SICC, and both currents are observed at higher latitudes during EQ2 than during EQ1, when the equatorial westward flow that they encompass appears with a weaker latitudinal extent. The SICC (NICC) transport, estimated between $\sigma_{0}=27.0$ and $\sigma_{0}=27.15$, is $4.1 \mathrm{~Sv}(6.2 \mathrm{~Sv})$ at $23^{\circ} \mathrm{W}, 6.5 \mathrm{~Sv}(3.4 \mathrm{~Sv})$ at $10^{\circ} \mathrm{W}$ during EQ1 and $4.1 \mathrm{~Sv}(2.1 \mathrm{~Sv})$ at $10^{\circ} \mathrm{W}$ during EQ2 respectively. At $0^{\circ} \mathrm{E}$ there is an eastward flow $\left(10 \mathrm{~cm} \mathrm{~s}^{-1}\right)$ between $4^{\circ} \mathrm{S}$ and $5^{\circ} \mathrm{S}$ below $400 \mathrm{~m}$ depth; if this flow is linked to the SICC at $10^{\circ} \mathrm{W}$ we have no explanation for its poleward divergence (the $\mathrm{CTD}-\mathrm{O}_{2}$ stations were carried out between $3^{\circ} \mathrm{S}$ and $2^{\circ} \mathrm{N}$ only, thus no water mass determination is possible). Neither the SICC nor the NICC is found at $6^{\circ} \mathrm{E}$. In March 1995 around the same longitude, Mercier et al. [2002] did not observe any clear-cut signature of the NICC, but observed the SICC at $2^{\circ} \mathrm{S}$ below $600 \mathrm{~m}$ depth. While $S t S c 99$ indicate that these currents may extend unchanged zonally across the entire equatorial Atlantic, Schmid et al. [2001] suggest a longitudinal dependence of the NICC that supports an eastward weakening of this current.

\section{Discussion}

[s] The EUC velocity core lies within the thermocline and it gets closer to the surface as it flows eastward, following the zonal slope of the thermocline. At $0^{\circ} \mathrm{E}$, the upper part of the velocity core is eroded through mixing and upwelling processes, giving the impression that the EUC sinks below the thermocline. This is in agreement with observations carried out in 1982-1984 [Gouriou and Reverdin, 1992] and modelling studies [Wacongne, 1989; Wacongne and Piton, 1992]. More surprising is the disappearance of the EUC at $6^{\circ} \mathrm{E}$ close to the African coast in boreal summer 2000. Preceding observations clearly show the presence of the EUC in that season [Hénin et al., 1986]. The schematic of StSc99 (their Figure 4) shows that in boreal spring and summer the EUC splits into two poleward coastal undercurrents, the most important being the southward one feeding the GCUC, while in boreal fall and winter, it would partly branch off the equator before $1^{\circ} \mathrm{E}$. We cannot exclude that interannual variability [e.g., Merle et al., 1979] or high frequency equatorial waves [e.g., Weisberg, 1979] may be responsible for such a feature. The EUC has also been observed to disappear in the eastern Pacific during the 1982-83 warm event, as a consequence of the vanishing of the thermocline zonal slope [e.g., Halpern, 1987]. Numerical simulations either indicate an EUC going as far as the African coasts before veering within the GCUC or an EUC surfacing east of $10^{\circ} \mathrm{W}$ [e.g., Wainer et al., 1999]. These model differences are however very dependent upon the specified dissipation coefficients and mixing schemes.

[9] Our results confirm a downstream poleward shift of the SEUC and the NEUC, in agreement with observations in the Pacific Ocean [Rowe et al., 1999], and with theoretical considerations by Johnson and Moore [1997] who suggest that these currents are mostly dictated by the eastward shoaling of the thermocline and propagate nearly inertially. At $35^{\circ} \mathrm{W}$ the NEUC lies at $4^{\circ} \mathrm{N}$ and the SEUC at $3^{\circ} 30 \mathrm{~S}$, at $23^{\circ} \mathrm{W}$ the NEUC is found at $5^{\circ} 30 \mathrm{~N}$ and the SEUC at $4^{\circ} \mathrm{S}$. If we consider the potential vorticity conservation mechanism of Johnson and Moore [1997], the poleward shift of the NEUC during its eastward course would prevent it to enter the Gulf of Guinea. Our results compare relatively well with the schematic map of StSc99 (their Figure 5), that shows the northward shift of the NEUC and its termination within the Guinea Dome. However, StSc99 do not indicate a southward shift of the SEUC, but only its veering when getting near the African coast.

[10] In the western basin, Schott et al. [1998] describe the EIC as a westward flow located just beneath the EUC. In the Pacific Ocean, Firing et al. [1998] define the EIC as the westward flow between the SEUC and the NEUC above the $\sigma_{0}=27$ isopycnal, and they name Lower Equatorial Intermediate Current (LEIC) the westward current between the SICC and the NICC. Currents observed below the EUC from $35^{\circ} \mathrm{W}$ to $10^{\circ} \mathrm{W}$ between the SEUC and the NEUC and between the SICC and the NICC clearly exhibit different 
behaviours, and we consequently suggest to use for the Atlantic Ocean the definition given by Firing et al. [1998]. The EIC is very weak $\left(<5 \mathrm{~cm} \mathrm{~s}^{-1}\right)$ at $35^{\circ} \mathrm{W}$ and is replaced by an eastward flow at $23^{\circ} \mathrm{W}$ and $10^{\circ} \mathrm{W}$. On the other hand, the LEIC is found at $23^{\circ} \mathrm{W}$ and at $10^{\circ} \mathrm{W}$ during the two cruises. SOFAR float trajectories showed strong variability in the western basin at the depth of the Antarctic Intermediate Water, i.e. roughly between 600 and $1000 \mathrm{~m}$ [Schmid et al., 2001]. Reversals of the EIC have also been noted in the Pacific Ocean, at least for two sections at $159^{\circ} \mathrm{W}$ in June 1983 and at $155^{\circ} \mathrm{W}$ in December 1989 [Firing et al., 1998]. While the presence of the EIC is suggested at $0^{\circ} \mathrm{E}$ around $150 \mathrm{~m}$ depth, neither EIC nor LEIC is observed at $6^{\circ} \mathrm{E}$. Mercier et al. [2002] did not find any EIC or LEIC neither at $7^{\circ} \mathrm{W}$ nor at $3^{\circ} \mathrm{E}$ in March 1995 . The absence of the SICC and the NICC at $0^{\circ} \mathrm{E}$ and $6^{\circ} \mathrm{E}$ constitutes a major difference with observations in the eastern Pacific, where they were seen as far east as $86^{\circ} \mathrm{W}$ in 1993 boreal spring [Firing et al., 1998]. In the Atlantic, StSc99 suggest that both currents split into two branches around $3^{\circ} \mathrm{E}$, with equatorward branches feeding the westward LEIC (their Figure 6). However, these differences may also be due to time and space variability, that are not resolved in these data sets.

[11] Acknowledgments. This work was supported by IRD (Institut de Recherche pour le Développenent), and the Programme National d'Etude de la Dynamique du Climat. We particularly thank Chantal Andrié, chief of the Equalant project, for her enthusiasm and friendly encouragements, Marion Bodichon, Frédéric Marin, Herlé Mercier, Lien Hua', Michel Arhan and Anne Marie Tréguier for their interest in this work and fruitful discussions. Many thanks to the officers and crew of R/V Thalassa for their help and cooperation.

\section{References}

Arhan, M., H. Mercier, B. Bourlès, and Y. Gouriou, Hydrographic sections across the Atlantic at $7^{\circ} 30 \mathrm{~N}$ and $4^{\circ} 30 \mathrm{~S}$, Deep Sea Res., 145, 829-872, 1998.

Boebel, O., R. E. Davis, M. Ollitrault, R. G. Peterson, P. L. Richardson, C. Schmid, and W. Zenk, The Intermediate Depth Circulation of the western South Atlantic, Geophys. Res. Letters, 26, 3329-3332 1999

Bourlès, B., Y. Gouriou, and R. Chuchla, On the circulation in the upper layer in the western equatorial Atlantic, J. Geophiys. Res., 104(C9), 21,15I-21,170, 1999.

Eldin, G., Mesure de courants par les profileurs à effet Doppler de coque (S-ADCP), Campagne Equalant-2000, rapport de campagne à la mer Doc. Scient. et Techn. du Centre IRD de Bretagne, n²001-89, 2001.

Firing, E., S. E. Wijffels, and P. Hacker, Equatorial subthermocline currents across the Pacific, J. Geophys. Res., 103, 21,413-21,423, 1998.
Gouriou, Y., and G. Reverdin, Isopycnal and diapycnal circulation of the upper equatorial Atantic ocean in 1983-1984, J. Geophys. Res., 22, $25,165-25,179,1992$.

Halpern, D., Observations of annual and El Niño thermal and flow varialions along the equator at $0^{\circ} 110^{\circ} \mathrm{W}$ and $0^{\circ} 95^{\circ} \mathrm{W}$ during $1980-1985, \mathrm{~J}$. Geophys. Res., 92, 8197-8212, 1987.

Hénin, C. P. Hisard, and B. Piton, Observations hydrologiques dans l'océan Atantique équatorial (juillet 1982-août 1984). FOCAL, vol.l, Ed. ORSTOM, Coll. “Travaux el Documents " n'196, Paris, 1986.

Hisard, P., and C. Hénin, Response of the Equatorial Alantic Ocean to the 1983-1984 wind from the Programme Français Océan et Climat dans l'Atlantique Equatorial cruise data set, J. Geophys. Res., 92, C4, 3759$3768,1987$.

Johnson, G. C., and D. W. Moore, The Pacific subsurface countercurrents and an inertial model, J. Phys. Oceanogr:, 27, 2448-2459, 1997.

Mercier, H., M. Arhan, and J. R. E. Lutjeharms, Upper-layer Circulation in the eastern Equatorial and South Atlantic Oceans in January-March 1995, submitted to Deep-Sea Res., 2002.

Merle, J., M. Ficux, and P. Hisard, Annual signal and interannual anomalies of sea surface temperature in the eastern equatorial Atlantic Ocean, DeepSea Res., suppl. II, 26, 77-102, 1979.

Peterson, R. G., and L. Stramma, Upper-level circulation in the South Atlantic Ocean, Prog. Oceanog, 26, 1-73, 1991.

Rowe, G. D., E. Firing, and G. Johnson, Pacific Equatorial Subsurface Countercurrent velocity, transport, and potential vorticity, J. Plys. Oceanogr:, 30, 1172-1187, 1999.

Schmid, C., R. L. Molinari, and S. L. Garzoli, New observations of the intermediate depth circulation in the tropical Atlantic, J. Mar: Res., 59, $281-312,2001$

Schott, F. A., L. Stramma, and J. Fischer, The warm water inflow into the western tropical Atlantic boundary regime, spring 1994, J. Geoplyss. Res., I00(C12), 24,745-24,760, 1995.

Schott, F. A., J. Fischer, and L. Stramma, Transports and pathways of the upper-layer circulation in the westem tropical Atlantic, $J$. Phys. Oceahogr:, 28, 1904-1928, 1998.

Stramma, L., and F. A. Schott, The mean flow field of the tropical Atlantic Ocean, Deep-Sea Res., II, 46(29), 279-303, 1999.

Tsuchiya, M., Thermostads and circulation in the upper layer of the Atlantic Ocean, Prog. Oceanog., 16, 235-267, 1986.

Wacongne, S., Dynamic regimes of a fully non linear stratified model of the Atlantic Equatorial Undercurrent, J. Geophys. Res., 94, 4801-4815, 1989.

Wacongne, S., and B. Piton, The near-surface circulation in the northeastern comer of the South Atlantic ocean, Deep-Sea Res., 39(7/8), 1273-1298, 1992.

Wainer, I., F. O. Bryan, and J. Soares, Dynamics of the Equatorial Undercurrent in a high resolution ocean model, J. Geophys. Res., 104(C10), $23,327-23,335,1999$

Weisberg, R. H., Equatorial waves during GATE and their relation to the mean zonal circulation, Deep-Sea Res., suppl. H, 26, 179-198, 1979.

B. Bourlès and R. Chuchla, Centre IRD de Brest, Plouzané, France. M. D’Orgeville, LPO/Ifremer, Plouzané, France.

G. Eldin and Y. DuPenhoat, IRD, LEGOS, Toulouse, France.

Y. Gouriou, Centre IRD de Nouméa, France.

$S$. Arnault, IRD, LODYC, Paris, France. 